UDC 504.42(045)

George O. Biliavskiy, Doctor of Geological and Mineralogical Sciences, Prof.

Armine V. Golod, post-graduate student

\title{
PECULIARITIES OF CONTAMINATION OF THE BLACK SEA
}

Article is devoted to meaningfulness estimation of some factors in forming ecological conditions in regions of the Black Sea. Comparative estimation of anthropogenic contamination degree of sea regions environment considered. The regions the most unhappy in ecological attitude are defined, that allows to mark first and foremost arrangements on improvement of ecological situation of the Black Sea.

Присвячео очінці значущзості деяких чинників у формуванні екологічних умов у регіонах Чорного моря. Надано порівняльну оиінку рівня антропогенного забруднення морських регіонів. Виділено регіони, найнесприятливіші в екологічному відношенні, щзо дозволяє відзначати аранжування на удосконаленні екологічної ситуації в Чорному морі.

ammonia, Azov Sea, Black Sea, ecological crisis, ferlizers, heavy metals, marine dumping, military forces, municipal wastes, nitrates, nitrogen, oil products, pesticides, pollution

\section{Introduction}

The Black Sea coastline of Ukraine extends from the Danube Delta in the west to the Kerch in the east. It has a length of $1.802 \mathrm{~km}$. The Azov Sea is within the Black Sea basin and is connected to the Black Sea through the Kerch Straits. It has a total length of $825 \mathrm{~km}$. The coastal zone is made up of four major landscape types. These can be summarized as the northern steppe sub-zone (e.g. Azov highland and lowland), middle steppe sub-zone (e.g. Dnister lowland, Dnipro-Molochanski lowland), arid steppe sub-zone (Black Sea lowland, Low Dnipro terrace, Sivash-Azov lowland) and the country of mountainous Crimea. Ninety-eight percent of the territory of Ukraine is located within the Black Sea basin, comprising major river basins:

- the Dnipro;

- the Dnister;

- the Southern Bug;

- the Siversky Donets;

- the Danube.

Wetlands are an important feature of the Ukrainian Black Sea basin, where the ten most significant wetland areas cover an area of 760.000 ha.

In the Black Sea coastal zone of Ukraine there are six administrative units: Odessa. Mykolayiv, Kherson, Zaporizhia, Donetsk regions and the Autonomous Republic of Crimea (ARC).

Three of the administrative units, which make up' the Crimea do not border the Black Sea but have close access to it.
The description of pollution examines the relation between types and levels of activities and flows of pollutants. The main source of effluent into the Black Sea, both in municipal and industrial wastewater discharges are the Odessa and the Crimea regions. Pollution from agricultural sources has been a serious problem since the $1980 \mathrm{~s}$ as overuse of these chemicals resulted in a tremendous pollution of soils, ground and surface waters as well as to the Sea itself. However, pesticide and fertilizer use has decreased by almost fifty percent in Ukraine in the past six years due to a decrease in agricultural production rather than to an improvement in managerial practices or a change in governmental policies. Pollution from transportation occurs mainly from the cities of Odessa, Illyichivsk and Sevastopol. Oil pollution is declining. Although there are two nuclear plants, radioactive pollution has not been detected.

Pollution from military sources and marine dumping is also recorded. Finally, a substantial source of Black Sea pollution is the input (treated as point sources) from the major rivers passing through Ukraine, in which concentrations of oil products, ammonium, nitrogen, nitrates and phenols have been discharged and monitored for the past two decades.

\section{Municipal Sewage}

Municipal sources of sewage are frequently among the most dangerous for the marine environment. Solutions to municipal sewage problems involve improved use of wastewater treatment technology. 
The Maximum Allowable Concentration (MAC) is used as a measuring device for comparing levels of different pollutants.

Maximum Allowable Concentration is the concentration of a particular pollutant that has been deemed acceptable under law.

Too frequently, when describing levels of pollution, is a question of stating the appropriate multiple of the MAC. Thus, in 1992, synthetic surfactants in discharge waters were determined to be up to three times the MAC (National Report on State. 1993). Pollution of coastal waters with phenols is high (3-7 MACs) and they are fairly evenly distributed throughout the marine coastal zone. Detergents are found practically everywhere in the coastal waters and their average concentration is 2-3 MACs.

Municipal sources of water pollution have been quantified in a 1996 the Black Sea Environmental Programme (BSEP)-sponsored report entitled «Assessment of land-based sources of water and land pollution on the Ukrainian Black Sea Coast». Source levels were estimated based on the number of permanent inhabitants of the areas in question. Some 16 wastewater treatment facilities are found in the coastal zone. The method of treatment is almost uniformly biological.

In 1993-94 the highest volumes of wastewater were treated by the Pivdenna and Sevastopol plants, which together handled of 1 17,5 million metres of wastewater annually.

\section{Industrial Effluents}

Concentrations of 19 heavy metals frequently exceed the MACs in all Black Sea coastal areas. The most serious offenders are $\mathrm{Co}, \mathrm{Zi}, \mathrm{Cd}, \mathrm{Co}, \mathrm{Ni}$, and $\mathrm{Cr}$. In the coastal waters near Crimea, seasonal variations in copper concentrations are associated with the use of copper-containing pesticides. Levels of iron and mercury are high (1,5-2 MACs), as are those of nutrients and phenols (3-7 MACs). Distribution of phenols is homogeneous throughout the coastal waters. The average concentration of detergents, which are also found throughout the coastal waters, is $2-3^{\wedge} \mathrm{MACs}$. As with municipal wastewater discharges, the main sources of industrial wastewater discharge into the Black Sea are the Odessa region and ARC.

The above-described assessment has also generated estimates for pollutant flows due to industry. Industrial sources of water pollution were considered in cases where they dump directly into the Black Sea or into lakes, which are channeled to the sea (average means 1993-1994).

\section{Atmospheric emissions}

Another important issue in the Black and Azov Sea coastal zones is air pollution from industry. The dynamics of air pollutant emissions by industries in the coastal zones are similar to pollutant dynamics nationally. Air pollution there mainly comes from the metallurgical, energy, coal mining and chemical industries situated in the Donetsk, Zaporizhia, and Kherson regions. Due to the sharp decline in industrial output throughout Ukraine and in these industries in particular, total emissions have decreased dramatically.

\section{Diffuse Agricultural Sources}

One reason for the deteriorating quality of soils in coastal regions is the irrational use of agricultural chemicals, which results in an accumulation of mineral fertilizers and pesticides in soils. As one indicator of the extent of the problem, it is estimated that $54 \%$ of farms do not have storage places for chemical fertilizers.

In the 1980s, the overuse of mineral fertilizers and pesticides was tremendous. There was a centralized system for pesticides and fertilizers distribution and state subsidies for purchasing them for agricultural enterprises (collective farms or kolkhozs and socialistic farms or sovkhors).

This policy resulted in widespread pollution of soils, ground and surface waters, and marine areas, namely the Black and Azov Seas.

Demand for mineral fertilizers in Ukraine is estimated at 7 million tons a year, most of which were brought from Russia in the time of the former Soviet Union. Even in the most successful years, demand for mineral fertilizers was not covered by local production. Currently, three Ukrainian plants (Vinytsya, Sumy and Donetsk) produce approximately $600000 \mathrm{t}$ of phosphorus fertilizers a year, which is not sufficient to meet the country's needs.Pesticide pollution and related ecological problems in the marine and terrestrial ecosystems of the Black and Azov Sea coastal zones have always been problems of great concern.

Discharge of pesticides with drainage and irrigation waters is one of the most important pathways for pollutants reaching the marine environment. 
For example, discharge of drainage water of the Krasnoznamensk irrigation system from 1986 to 1988 caused the pollution of Dzhagarlyk Bay. The most persistent and dangerous pesticides, including DDT, are no longer permitted in Ukraine. Nevertheless, persistent organochlorine peslicides will long represent a source of marine pollution.

\section{Agricultural wastes}

In addition to the above-described sources of pollution, agriculture in the Black and Azov Sea coastal regions and rivers is a significant source of organic compounds and nutrients. Eutrophication of marine coastal waters is the most significant problem. Especially great number estimated loads of liquid wastes from farming in the coastal regions.

\section{Pollution from the Energy and Transport}

In 1993, enterprises from the energy sector, including coal mining, released an estimated $51 \%$ of total air pollutants in Ukraine. Since 1992, coal use for heating has increased in Ukraine.

At the same time very few investments have been made in fuel energy industries. Investments in gas treatment facilities in this industry were minor.

High concentrations of priority pollutants stemming from the energy and transport sectors occur near big industrial centers, in river estuaries and in other coastal zone areas exposed to permanent pollution.

The main pollutants in Black Sea coastal waters are oil products.

Their concentration on the surface varies from 0,05 to $0,78 \mathrm{mg} / \mathrm{L}$ ( 1 to $13 \mathrm{MACs}$ ). Much of this oil has been released from enterprises with in the energy and transport sectors.

The most polluted areas are those located near Odessa: Illyichivsk, Sevastopol and other coastal cities. The concentration of oil products in Sevastopol Bay is 5MACs and sometimes exceeds 100 MACs.

At present there is a trend towards decreased oil pollution in all coastal regions. For example, in the Odessa region, the mean concentration fell from 10 MACs in 1989 to I MAC in 1993. This trend is connected with the general decreased level of industrial activities in Ukraine.
Nevertheless the accumulation of oil products in bottom sediments persists, reaching levels as high as $13 \mathrm{~g} / \mathrm{kg}$.

There are more than 30 marine transport enterprises in the coastal zone of Ukraine which influence the ecological condition of the marine environment and air in the basin.

They include ports, both major ones, e.g. Odessa. Pivdenna, Illichivsk, Ust-Dunaisk, Yalta, Kerch and Izmail, as well as smaller ones, e.g. Kiliya, Bilgorod-Dnistrovsky, Ochakiv, Mykolayiv, Kherson, Skadovsk, Yevpatoriya, Sevastopol, Feodosiya, Vylkovo, Bugaz, Oktiabrsk, Khorly, Inkerman and Massandra. There are also a number of shipbuilding and ship repair yards. These enterprises discharge an estimated 7,5 million millilitres of untreated, and about 200 million metres of insufficiently treated, wastewater into the Black Sea coastal zone. As a result, 120 thousand tons of suspended matter and about $50 \mathrm{t}$ of oil products and other pollutants enter the sea annually.

Concentrations of mercury and arsenic in the marine ecosystem are low. Pollution of bottom sediments in the main ports is of special concern as it may cause secondary pollution from dredged materials. In addition to oil products, there are heavy metals, pesticides and other pollutants accumulated in bottom sediments that can cause secondary pollution of the coastal zone due to dumping of dredged materials. Finally, there are two nuclear plants in the Black and Azov Sea coastal regions: South-Ukrainian and Zaporizhia nuclear plants. Radioactive pollution from these plants has not been detected in the Black Sea. Radionuclides from the Chernobyl disaster were found in the bottom sediment and soils of the Black and Azov Sea coastal zones, though at very low levels.

\section{Other Sources of Pollution}

For many years pollution of the Black Sea from defense activities and the Black Sea Fleet was a state secret. The true impact of military activities on the marine environment has only been revealed during the last 5-6 years.

Major environmental problems related to military activities resulted from:

- oil pollution from the Black Sea fleet facilities (Sevastopol, Bakaklava, Kerch, Mykolayiv, Kherson);

- disposal of solid and toxic wastes (Sevastopol, Kerch); 
- hazardous high frequency irradiation (Feodosiya, Kerch, Sevastopol, Ochakiv);

- shipwrecks and intentional ship sinking in war time (all big ports of the Black Sea);

- noise pollution from submarines, aircraft carriers, etc.;

- a large amount of chemical weapons was disposed in Kozachiya Bay;

- Inkerman navy base, which has been a polluter of the marine environment for 50 years;

- pollution from war exercises.

By expert estimation, pollution of the Black Sea from military activities consists of 7 thousand $\mathrm{m}^{3}$ of polluted wastewater and $10 \mathrm{t}$ of oil products a day.

Sevastopol Bay is the most polluted in the coastal zone. In 1992-1994, oil pollution levels caused by military activity frequently exceeded the relevant MAC by several hundred times and in some places by 2000 times.

\section{Marine Dumping}

Marine dumping of solid wastes and bottom sediments from dredging marine navigation canals are an important source of Black and Azov Sea pollution. According to data of the regional sanitary and epidemiological centers, within the boundaries of the northwestern area of the Black Sea, more than 5 million cubic metres of solid wastes have been dumped in the past 20 years.

In Kerch Strait during the last seven years 21 million cubic metres of soil were dumped. There are more than 30 dumping sites in the Black Sea coastal zone, and 10 in the north-western coastal zone.

The volume of dumped wastes in the Danube River estuary doubled between 1980 and 1985. During construction of the Pivdenny Port in Odessa, quantities of dumped soil reached 4 million cubic metres (1,5 times more than joint annual suspended solid discharge of the Dnipro and Southern Bug Rivers).

The rate of soil and solid waste accumulation at dumping sites exceeds the natural sedimentation rate by more than 1,000 times. Marine ecosystem functions may be heavily impacted.

Marine sand extraction for the building industry results in decreases of photosynthetic activity and bioproductivity.

\section{Conclusion}

This article on pollution in the Black Sea examines the relation between types and levels of activities and flows of pollutants.

The main source of effluent into the Black Sea, both in municipal and industrial wastewater discharges, are the Odessa and the Crimea regions.

Pollution from agricultural sources has been a serious problem since the 1980s as overuse of these chemicals resulted in a tremendous pollution of soils, ground and surface waters as well as the Sea itself. However, pesticide and fertilizer use has decreased by almost fifty percent in Ukraine in the past six years due to a decrease in agricultural production rather than to an improvement in managerial practices or a change in governmental policies.

Pollution from transportation occurs mainly from the cities of Odessa, Illyichivsk and Sevastopol. Oil pollution is declining. Although there are two nuclear plants, radioactive pollution has not been detected.

Pollution from military sources and marine dumping is also recorded. Finally, a substantial source of Black Sea pollution is the input (treated as point sources) from the major rivers passing through Ukraine, in which concentrations of oil products, ammonium, nitrogen, nitrates and phenols have been discharged and monitored for the past two decades.

Using the data collected, hot spots were identified and remedial projects developed. These projects were then prioritized using a common methodology and a grading system was applied. The grading system was specifically used to determine the risk of the pollution hot spots on public health, drinking water quality, natural aquatic life, wetlands, recreational areas and other beneficial uses of the Sea, as well as on welfare and the economy. A multiplier effect was incorporated in the grading system, based on the importance of the effected entry. Transboundary effects of the pollution hot spots were also assessed.

According to the list of investments, the $410 \mathrm{~km}$ of sewers and wastewater plants capable of handling 1.4 million $\mathrm{m}$ /day require construction and renovation at a cost of approximately 660 million USD. Additional investments that would be required to stop marine 
dumping, protect bio-diversity areas and to establish the sustainable economic developments are necessary. From this long list of projects a short list often pollution hot spots was identified by the BSEP worth H2.5 million USD. The investment portfolio to be developed as part of the National Black Sea Strategic Action Plan (NBS-SAP) is expected to include many if not all of these hot spot projects.

The Ukrainian economy is under a lot of pressure and is facing a serious crisis. GDP has fallen by $55 \%$, national income by $59 \%$ and consumption by $32 \%$. The most important Black Sea industrial centers are in Odessa and in the Crimea. Despite the overall decline in industrial output since 1991, the rate of decline in the coastal zone is lower than the national average. The main industries on the coastal zone are currently machine building, metallurgy, food, consumer goods and construction materials. These industries are highly polluting to coastal waters. As in the case of agriculture, the decline in industrial production resulted in a reduction of the pollution load, which is not the outcome of any improvement in treatment capacity or efficiency. There has also been a decrease in fish catches in the past two decades and although tourism has been a significant industry for the coastal zone, the deterioration of water quality has led to its recent decline. However, tourism remains a potential area for growth.

The current economic crisis is largely perceived to be the outcome of tine former centrally-planned system. Environmental spending used to be among the lowest priority areas of the government. Unfortunately, this attitude has only changed slightly; expenditure on environmental spending in 1990 was 1,3\% of GDP and increased only marginally to $2,7 \%$ in 1994 .
The Ministry of Environmental Protection and Nuclear Safety of Ukraine has proposed an increase of environmental expenditures up to a level of $3-5 \%$ of GDP. Further, an increase of environmental protection funds is expected in local budgets.

\section{References}

1. Borysova E. Eutrophication in the Black Sea Region / Elena Borysova, Andrey Kondakov, Felix Stolberg // Impact assessment and causal chain analysis. - Sweden, 2005. - P. 60 .

2. Neal Ascherson. Black Sea. The Birthplace of Civilisation and Barbarism. - London, 1996.

3. Osokina N.P. Pesticides Content in the Bottom Sediments of the West NW Part of Black Sea Shelf (O. Zmeinyj) / N.P. Osokina, A.J. Mitropolskij // Carpathian-Balkan Geol. - Vienna, 1998. - P. 444.

4. Osokina N.P. Pesticides in Surface and Bottom Water in West NW Part of Black Sea Shelf (O. Zmeinyj) / N.P. Osokina, A.J. Mitropolskij // 8th Annual of Meeting of SETAC-Europe. - Bordeaux, France, 1998. - P. 84.

5. Osokina N.P. Pesticide content of the Black sea and sea of Azov and protection from human-induced pollution at land use / N.P. Osokina // Abstracts thid european conference on ecotoxicology. - Zurich. Switzerland, 1998. - P. 312.

6. Seragildin I. Making Development Sustainable. From Concepts to Action / I. Seragildin, A. Steer (Eds.) // Environmental Sustainable Development Occasional Paper Series. \# 2. - The World Bank, Washington, D.C. -1994.

7. Safranov T.A. Contamination peculiarities of mouth zones of north-western part of Black Sea / T.A. Safranov, A.V. Chugai // Transboundary Pollution. 4th International Conference of the Balkan Environmental Association B.EN.A. Abstracts. October 2001. - Edirne, 2001. - P. 246.

8. Vershinin A.O. Life of the Black Sea / A.O. Vershinin. M:. MAKCENTER, 2003. - 176 c. 